\title{
Azacitidine-associated Acute Interstitial Pneumonitis
}

\author{
Junya Kuroda, Yuji Shimura, Shinsuke Mizutani, Hisao Nagoshi, Miki Kiyota, \\ Yoshiaki Chinen, Saori Maegawa, Tsutomu Kobayashi, Yosuke Matsumoto, \\ Shigeo Horiike and Masafumi Taniwaki
}

\begin{abstract}
Azacitidine is the first-line therapeutic option for myelodysplastic syndrome (MDS). This report describes a case of MDS in a patient who developed fatal acute interstitial pneumonitis (AIP) after the first seven-day course of intravenous azacitidine $\left(75 \mathrm{mg} / \mathrm{m}^{2} /\right.$ day) treatment. A review of previous and present studies of azacitidine-associated AIP suggests that azacitidine may cause life-threatening AIP during or after the first seven-day course of treatment, with pyrexia commonly preceding AIP. Although the non-hematologic adverse events associated with azacitidine are generally relatively mild, further accumulation of evidence may help to make an earlier diagnosis of azacitidine-associated AIP.
\end{abstract}

Key words: azacitidine, interstitial pneumonitis, adverse event

(Intern Med 53: 1165-1169, 2014)

(DOI: 10.2169/internalmedicine.53.1971)

\section{Introduction}

Azacitidine, the first-in-class clinically available DNA hypomethylating agent, has been used as the first-line treatment for myelodysplastic syndrome (MDS) since a clinical study demonstrated the superiority of azacitidine over best supportive care and conventional chemotherapy incorporating cytarabine and anthracycline $(1,2)$. Although therapy with azacitidine is commonly well tolerated and can be administered in the outpatient setting, safety data for azacitidine indicate the occurrence of various types of common hematologic and non-hematologic chemotherapy-associated adverse events. The latter include relatively frequent gastrointestinal events, such as nausea, vomiting, constipation or diarrhea, pyrexia, fatigue, mucositis, local injection site reactions, etc., as well as rare but severe adverse events, such as coma (2-4). Although not mentioned in reports of large clinical trials among both Caucasian and Asian patients $(2,3,5)$, several recent studies have reported the development of noninfectious acute interstitial pneumonitis (AIP) in association with azacitidine treatment in MDS patients (6-10). Although this event is extremely rare, further accumulation of evidence may help to make an earlier diag- nosis and improve decision making regarding the optimal treatment of azacitidine-associated AIP. This article describes the case of a patient with MDS whose disease was complicated by fatal AIP during the first course of azacitidine treatment. In addition, we review previous case reports to identify the clinicopathologic characteristics of azacitidineassociated AIP in MDS patients.

\section{Case Report}

A 72-year-old man came to our hospital complaining of general fatigue and dyspnea on exertion. He had a history of coronary arterial stenosis that had been successfully treated with interventional catheterization, and a systemic examination performed on admission excluded a diagnosis of symptomatic heart failure. The results of a peripheral blood examination showed pancytopenia with a white blood cell count of $2.6 \times 10^{9} / \mathrm{L}$ containing $34 \%$ neutrophils and $2 \%$ abnormal myeloblasts, with a hemoglobin level of $8.2 \mathrm{~g} / \mathrm{dL}$ and a platelet count of $26 \times 10^{9} / \mathrm{L}$. Other laboratory findings on admission are summarized in Table 1. A bone marrow analysis showed hypocellularity $\left(23 \times 10^{9} / \mathrm{L}\right)$ with trilineage dysplastic features and an abnormal increase in myeloblasts, accounting for $6.2 \%$ of all nucleated cells. A karyotype 
Table 1. Laboratory Findings on Admission

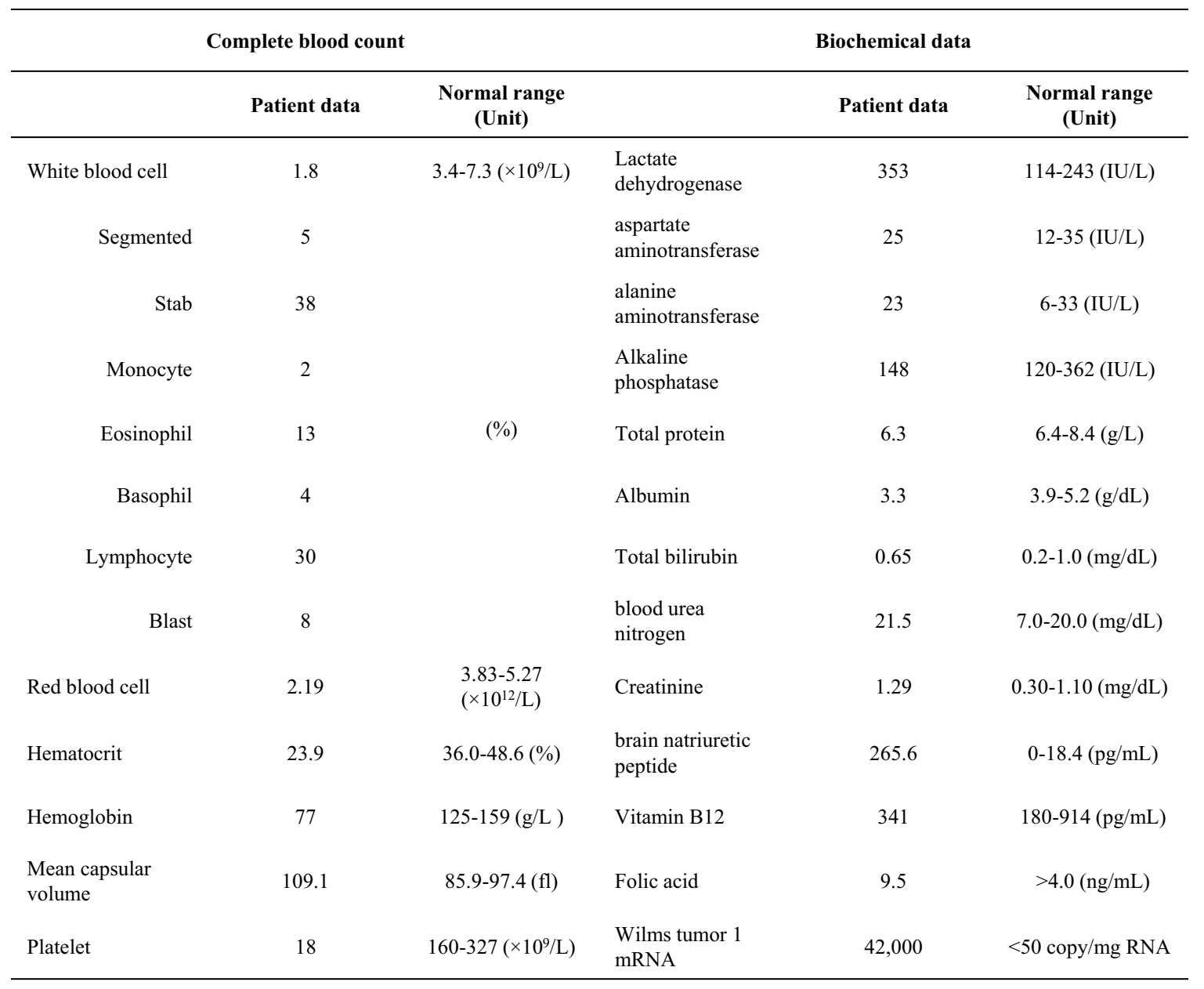

analysis using G-banding identified a high-risk abnormality: 46, XY, der(1;7)(q10;p10) [17/20]. This combination of findings led to a diagnosis of hypoplastic MDS and refractory anemia with an excess of blasts (RAEB)-1 based on the WHO classification. The patient received azacitidine (75 $\mathrm{mg} / \mathrm{m}^{2} /$ day) intravenously for seven days and subsequently developed moderate pyrexia up to $37.5^{\circ} \mathrm{C}$ from day 3 to 5 of treatment. His temperature further rose to $38.0^{\circ} \mathrm{C}$ on day 6 without any signs of an infectious disease. During this period, his other vital signs were normal, including an oxygen saturation level between $96 \%$ and $98 \%$ on room air. On day 7 , he began to complain of dyspnea, a dry cough and a small amount of bloody sputum and wheezing associated with progressive hypoxic respiratory failure requiring oxygen supplementation. At that time, a chest X-ray showed patchy airspace disease in the right upper field and bilateral lower fields (Fig. 1b). A computed tomography scan demonstrated areas of interstitial opacity and ground glass shadowing in the right upper field and bilateral mid-to-lower fields (Fig. 2a-c), as well as mediastinal lymph node swelling and a small amount of bilateral pleural effusion (Fig. 2d). Treatment with broad-spectrum antibiotics and antifungal agents was initiated, although no infectious agents were identified on advanced microbiologic or virologic examinations, including microbacterial and mycobacterial cultures of the sputum and blood and tests for cytomegalovirus antigenemia, Aspergillus and Cryptococcus neoformans antigens, $\beta$ D-glucan for fungal and Pneumocystis jirovecii infection and the procalcitonin level. While the serum $\mathrm{C}$-reactive protein and surfactant protein (SP)-A levels had increased to 10.22 $\mathrm{mg} / \mathrm{dL}$ (normal range: $0.00-0.20 \mathrm{mg} / \mathrm{dL}$ ) and $63.8 \mathrm{ng} / \mathrm{mL}$ $(0.0-43.7 \mathrm{ng} / \mathrm{mL})$, respectively, the serum sialylated carbohydrate antigen (KL-6), SP-A and immunoglobulin E levels remained within the normal ranges. The patient's symptoms persisted for the next four days without any improvements, and a chest X-ray showed worsening of the patchy and reticulogranular shadowing (Fig. 1d). Based on the Naranjo algorithm for assessing the causality of adverse drug reactions (11), we made a probable diagnosis of azacitidineassociated AIP. Indeed, the patient's subsequent clinical course, including migrating abnormal pulmonary shadowing (Fig. 1a-h) without laboratory results indicating infectious disease or a response to various types of antimicrobial agents, further supported the diagnosis of drug-induced AIP. The patient was therefore treated with intravenous methylprednisolone $(500 \mathrm{mg})$ for four days, followed by high-dose corticosteroid therapy in combination with sulfamethoxazole trimethoprim, vancomycin and micafungin. His respiratory condition transiently improved for two days, although it worsened again on day 14 after the start of azacitidine treat- 

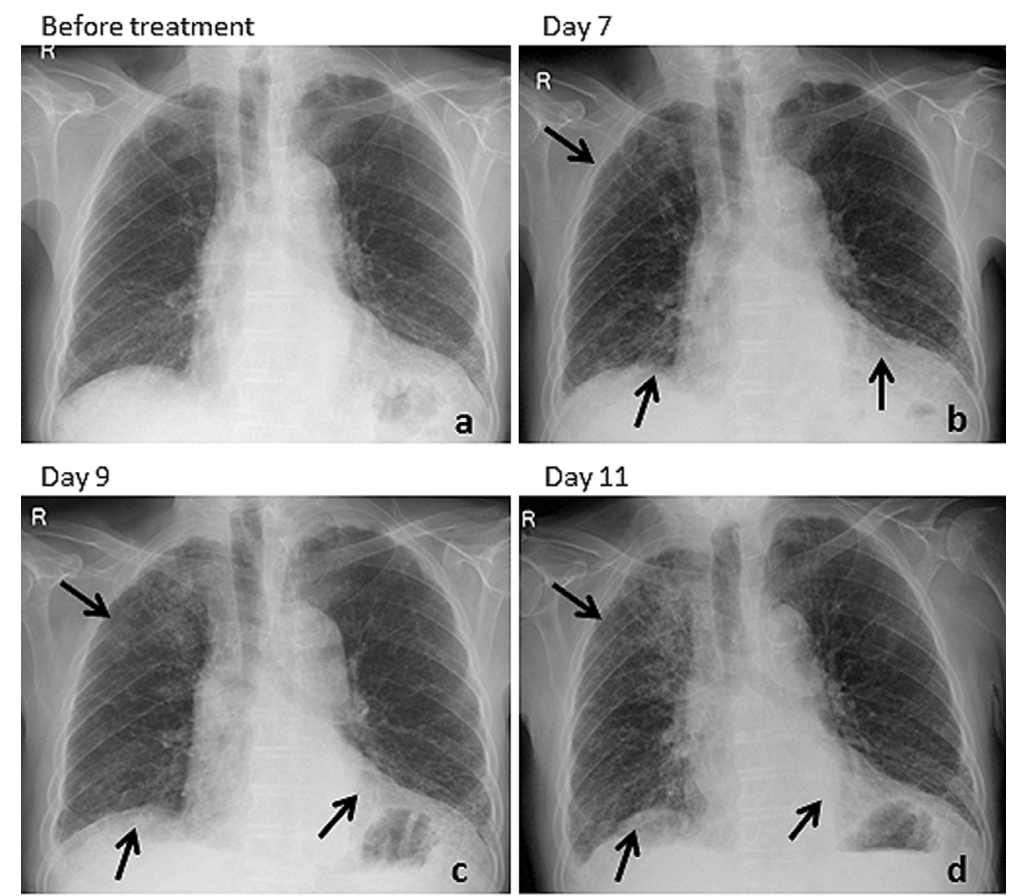

Day 11
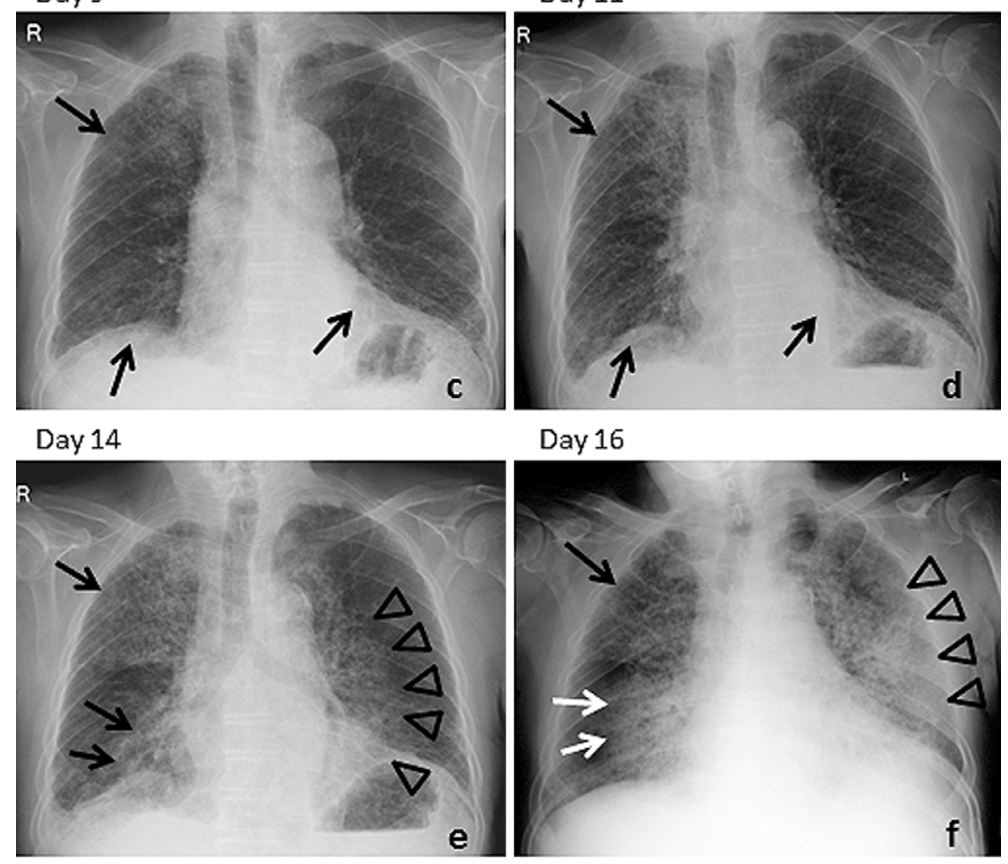

Day 16

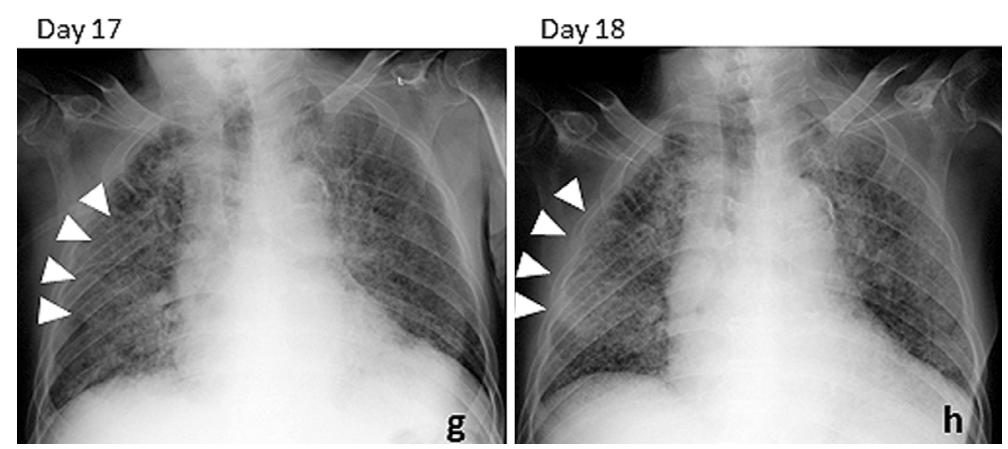

Figure 1. Sequential chest $\mathrm{X}$-ray findings and treatment and clinical results. a: Before azacitidine treatment. b: Day 7 of azacitidine treatment at the onset of pneumonitis. The arrows indicate the affected lesions. The patient received cefepime (CFPM) and fluconazole (FLCZ). c: Day 9. Worsening of patchy shadowing in the right upper field was observed. CFPM and FLCZ were changed to meropenem and micafungin. d: Day 11. Further worsening of the patchy and reticulogranular shadowing in both the right upper and bilateral lower fields was observed. The patient received methylprednisolone pulse therapy. Vancomycin and sulfamethoxazole trimethoprim were added. e: Day 14. Further worsening of the preexisting lesions (arrows) and the development of a new lesion around the left hilum (triangles) were identified. The patient exhibited progressive respiratory failure. f: Day 16. Worsening of the condition of the right lower field (white arrows) and left middle peripheral field (triangles) was observed, while the right upper field demonstrated a slight improvement (arrows). g: Day 17. A new lesion was identified in the right middle peripheral field (white triangles). A slight improvement of the other lesions was also observed. The patient exhibited progressive multiorgan failure. h: Day 18. Worsening of the right middle peripheral lesion was observed despite improvements in the other lesions. The patient died the following day without any improvements in his respiratory condition. 

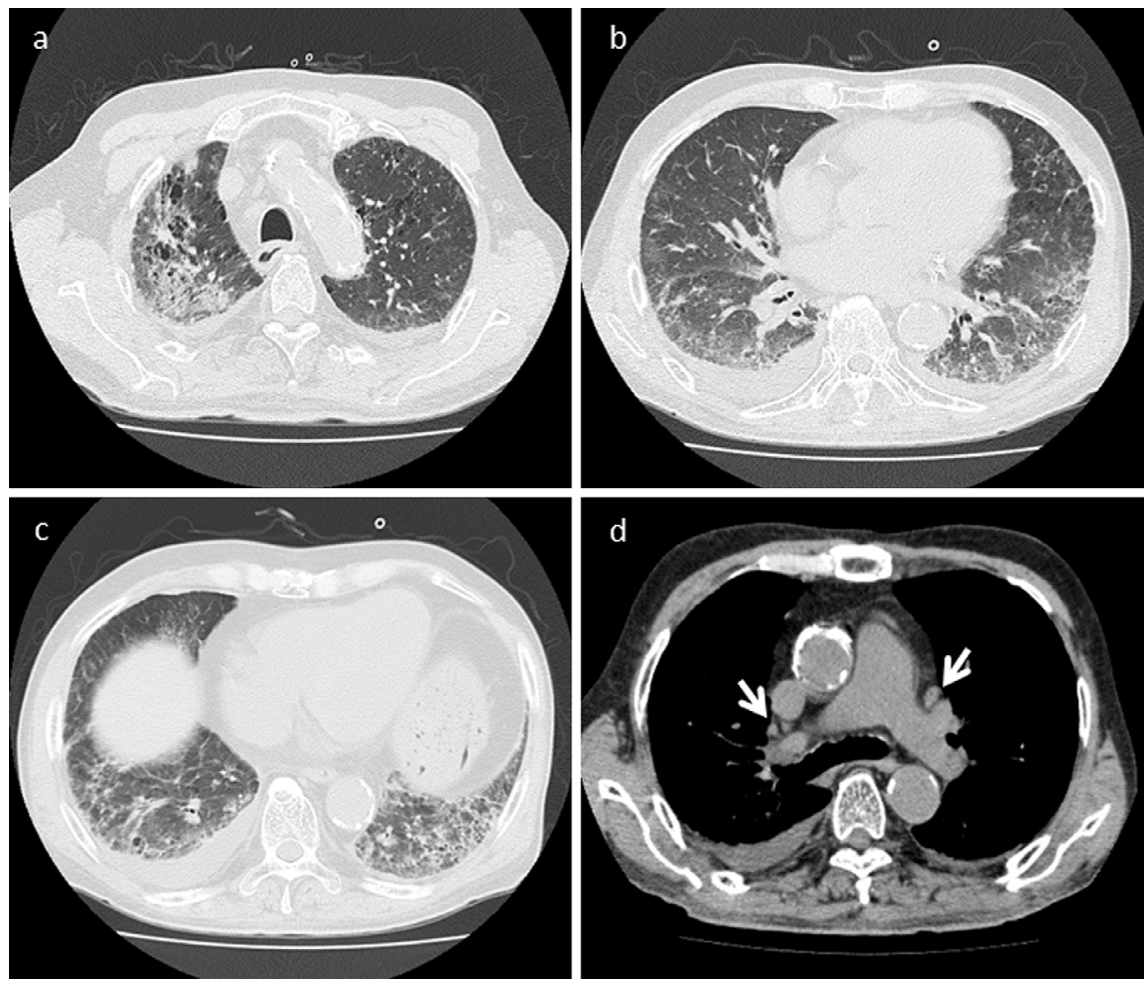

Figure 2. Computed tomography scan of the chest at the diagnosis of interstitial pneumonitis. A predominantly peripheral reticular pattern with honeycombing and ground-glass opacity was observed in a: the upper field, b: middle field and c: lower field. d: Mediastinal lymph node swelling was also observed (arrows).

Table 2. Clinicopathologic Features of MDS Patients with Azacitidine-associated Acute Organizing Pneumonia/interstitial Pneumonitis

\begin{tabular}{|c|c|c|c|c|c|c|c|c|c|c|c|c|c|c|}
\hline$\#$ & $\begin{array}{l}\text { Age } \\
\text { /Sex }\end{array}$ & $\begin{array}{c}\text { MDS } \\
\text { subtype }\end{array}$ & $\begin{array}{c}\text { Clinical } \\
\text { diagnosis } \\
\text { of lung } \\
\text { disease }\end{array}$ & $\begin{array}{c}\text { Ante- } \\
\text { mortem } \\
\text { biopsy }\end{array}$ & $\begin{array}{l}\text { Reported } \\
\text { radiographic } \\
\text { finding }\end{array}$ & $\begin{array}{l}\text { Affected } \\
\text { pulmonary } \\
\text { lesion }\end{array}$ & $\begin{array}{l}\text { Pleural } \\
\text { effusion }\end{array}$ & $\begin{array}{c}\text { Duration } \\
\text { from } \\
5 \text {-Aza } \\
\text { treatment }\end{array}$ & $\begin{array}{l}\text { 5-Aza } \\
\text { cycle }\end{array}$ & $\begin{array}{c}\text { Initial } \\
\text { symptoms } \\
\text { before } \\
\text { respiratory } \\
\text { failure }\end{array}$ & $\begin{array}{c}\text { Initial dosage } \\
\text { and start date } \\
\text { of } \\
\text { high-dose } \\
\text { corticosteroid } \\
\text { therapy }\end{array}$ & $\begin{array}{l}\text { Mechanical } \\
\text { ventilation }\end{array}$ & Outcome & Ref. \\
\hline 1 & $\begin{array}{l}74 \\
/ F\end{array}$ & RAEB-1 & IP & $\begin{array}{ccc}1 \\
5\end{array}$ & $\begin{array}{l}\text { peribronchiolar } \\
\text { shadowing, pathcy } \\
\text { shadowing, reticulo- } \\
\text { nodular and ground } \\
\text { glass shadowing }\end{array}$ & $\begin{array}{l}\text { Bilateral } \\
\text { lower lobes }\end{array}$ & + & 3 weeks & $\begin{array}{l}1 \mathrm{st} \\
2 \mathrm{nd}\end{array}$ & $\begin{array}{l}\text { Pyrexia } \\
\text { Dry cough }\end{array}$ & $\begin{array}{c}\mathrm{mPSL} \\
1.5 \mathrm{~g} / \text { day } \\
\text { day } 3\end{array}$ & - & Improved & 6 \\
\hline 2 & $\begin{array}{l}71 \\
/ \mathrm{M}\end{array}$ & ND & OP & + & $\begin{array}{l}\text { patchy bilateral } \\
\text { perihilar airspace } \\
\text { disease }\end{array}$ & $\begin{array}{l}\text { Bilateral, } \\
\text { diffuse }\end{array}$ & + & $\begin{array}{l}\text { within } \\
1 \text { week }\end{array}$ & 1 st & $\begin{array}{l}\text { Wheezing, } \\
\text { Crackles } \\
\text { Pyrexia }\end{array}$ & ND & - & Died & 7 \\
\hline 3 & $\begin{array}{l}74 \\
/ \mathrm{M}\end{array}$ & RAEB-1 & $\mathrm{OP}$ & $\begin{array}{ll}0 \\
1 \\
1 \\
c \\
5\end{array}$ & $\begin{array}{l}\text { enlargement of } \\
\text { mediastinal lymph } \\
\text { node, non-segmental } \\
\text { consolidations with } \\
\text { airbronchogram, } \\
\text { surrounding ground- } \\
\text { glass shadow }\end{array}$ & $\begin{array}{l}\text { Right } \\
\text { middle field }\end{array}$ & + & $\begin{array}{l}\text { within } \\
1 \text { week }\end{array}$ & 1 st & $\begin{array}{l}\text { Cough } \\
\text { Shortness } \\
\text { of breath } \\
\text { Pyrexia }\end{array}$ & $\begin{array}{c}\mathrm{mPSL} \\
1.0 \mathrm{~g} / \mathrm{day} \\
\text { day } 31\end{array}$ & - & Improved & 8 \\
\hline 4 & $\begin{array}{l}56 \\
/ \mathrm{M}\end{array}$ & RAEB-2 & OP & c & $\begin{array}{l}\text { bilateral airspace } \\
\text { disease with many } \\
\text { areas of nodular } \\
\text { opacities }\end{array}$ & ND & ND & $\begin{array}{l}\text { within } \\
1 \text { week }\end{array}$ & $\begin{array}{l}1 \mathrm{st} \\
2 \mathrm{nd}\end{array}$ & $\begin{array}{l}\text { Dry cough } \\
\text { Dyspnea }\end{array}$ & $\begin{array}{c}\text { mPSL } \\
\text { Not described } \\
\text { precisely }\end{array}$ & + & Improved & 9 \\
\hline 5 & $\begin{array}{l}55 \\
/ \mathrm{F}\end{array}$ & tMDS & IP & - & interstitial opacity & $\begin{array}{l}\text { Bilateral, } \\
\text { diffuse }\end{array}$ & ND & $\begin{array}{l}\text { within } \\
1 \text { week }\end{array}$ & 1 st & $\begin{array}{l}\text { Pyrexia } \\
\text { Dyspnea }\end{array}$ & $\begin{array}{c}\mathrm{mPSL} \\
0.2 \mathrm{~g} / \text { day } \\
\text { day } 10\end{array}$ & + & Improved & 10 \\
\hline 6 & $\begin{array}{l}72 \\
/ \mathrm{M}\end{array}$ & RAEB-1 & IP & $\begin{array}{ll}6 \\
1 \\
1 \\
1 \\
5\end{array}$ & $\begin{array}{l}\text { enlargement of } \\
\text { mediastinal lymph } \\
\text { node, bilateral pathcy } \\
\text { shadowing, reticulo- } \\
\text { nodular and ground } \\
\text { glass shadowing }\end{array}$ & $\begin{array}{l}\text { Bilateral, } \\
\text { diffuse }\end{array}$ & + & $\begin{array}{l}\text { within } \\
1 \text { week }\end{array}$ & 1 st & $\begin{array}{l}\text { Pyrexia } \\
\text { Dyspnea }\end{array}$ & $\begin{array}{c}\mathrm{mPSL} \\
0.5 \mathrm{~g} / \text { day } \\
\text { day } 11\end{array}$ & - & Died & $\begin{array}{c}\text { Present } \\
\text { case }\end{array}$ \\
\hline
\end{tabular}

Start date of corticosteroid therapy: Day 1 indicates the first day of azacitidine treatment. Abbreviations: F: female; M: male; IP: interstitial pneumonitis; OP: organizing pneumonia; 5-Aza: azacitidine; mPSL: methylprednisolone; Ref: reference; ND: not described 
ment. Although the patient's respiratory failure progressed to an oxygen saturation of $70 \%$, even with maximum oxygen supplementation, he and his family refused mechanical ventilation. Despite the administration of intensive treatment with high-dose corticosteroids, antibiotics and antifungal agents supported by maximum oxygen supplementation for the next four days under sedation with low doses of morphine and midazolam, the patient died of multiorgan failure on day 19 after the initiation of azacitidine treatment.

\section{Discussion}

Many cytotoxic agents utilized in anticancer therapy can cause AIP, which may be life-threatening $(12,13)$. The management of AIP requires a quick diagnosis and prompt treatment, although obtaining a definitive diagnosis of druginduced AIP is not always straightforward, as it requires the physician to rule out other causative factors for lung disease, such as infectious diseases, in addition to performing a pathological assessment if possible. Because patients with MDS are generally highly immunocompromised and performing a lung biopsy is difficult due to their poor general condition and high risk of hemorrhage as a result of thrombocytopenia, as observed in the present case, it is difficult to make a quick and correct differential diagnosis between drug-induced AIP and infectious disease. In view of the lack of sufficient diagnostic tools, the accumulation of clinical findings in patients with drug-induced AIP can be expected to yield important information for daily clinical practice.

As far as we were able to determine based on a search of the English literature, there are six reports of MDS patients, including the present patient, with azacitidine-associated AIP (Table 2) (6-10). An antemortem lung biopsy was performed in only one patient, and the diagnosis of AIP in each case was primarily made based on radiological findings consistent with a diagnosis of organizing pneumonia or interstitial pneumonia, negative results for infectious agents and the lack of response to antimicrobial agents. The pulmonary characteristics varied among the patients, although the lesions were generally bilateral and diffuse, and a small amount of pleural effusion was common. The onset of AIP was primarily observed during or after the first course of azacitidine treatment, and the administration of a second course of azacitidine further worsened the AIP in two patients whose symptoms were relatively mild during the first course of therapy. Most patients presented with pyrexia prior to the onset of AIP and subsequently developed AIP within one week. Because moderate pyrexia is relatively common during the course of treatment with azacitidine (2-5), physicians must pay careful attention to the respiratory symptoms of febrile patients, even those without signs of infectious disease, during and after the first course of azacitidine treatment, so as not to overlook the signs of AIP. Although rele- vant information remains limited, the degree of pulmonary damage caused by azacitidine-associated AIP is likely to be severe. Two patients, including the present patient, died of azacitidine-associated AIP (7), while transient mechanical ventilation was required in two of the four patients who survived $(9,10)$. Although there was no diagnostically relevant pathological information regarding AIP in the present case, methylprednisolone pulse therapy $(500 \mathrm{mg} /$ body $\times$ four days) was started on day 5 (i.e., day 11 after the initiation of azacitidine treatment) based on the radiologic diagnosis of interstitial pneumonitis. It is conceivable that providing pharmacological treatment much earlier with high-dose corticosteroid therapy may have rescued our patient.

In conclusion, we herein reported a case of azacitidineassociated AIP. Because the mechanism underlying the development of azacitidine-associated AIP remains unknown and AIP is an extremely rare adverse event associated with azacitidine treatment, larger studies including such factors as genetic background factors are needed to improve the ability to identify high-risk patients.

\section{The authors state that they have no Conflict of Interest (COI).}

\section{References}

1. Fenaux P, Mufti GJ, Hellstrom-Lindberg E, et al. Efficacy of azacitidine compared with that of conventional care regimens in the treatment of higher-risk myelodysplastic syndromes: a randomised, open-label, phase III study. Lancet Oncol 10: 223-232, 2009.

2. Ornstein MC, Sekeres MA. Combination strategies in myelodysplastic syndromes. Int J Hematol 95: 26-33, 2012.

3. Silverman LR, McKenzie DR, Peterson BL, et al. Further analysis of trials with azacitidine in patients with myelodysplastic syndrome: studies 8421, 8921, and 9221 by the Cancer and Leukemia Group B. J Clin Oncol 24: 3895-3903, 2006.

4. Kaminskas E, Farrell AT, Wang YC, Sridhara R, Pazdur R. FDA drug approval summary: azacitidine (5-azacytidine, Vidaza) for injectable suspension. Oncologist 10: 176-182, 2005.

5. Uchida T, Ogawa Y, Kobayashi Y, et al. Phase I and II study of azacitidine in Japanese patients with myelodysplastic syndromes. Cancer Sci 102: 1680-1686, 2011.

6. Pillai AR, Sadik W, Jones PA, Thachil J. Interstitial pneumonitis-An important differential diagnosis for pulmonary sepsis in haematology patients. Leuk Res 36: e39-e40, 2012.

7. Adams CD, Szumita PM, Baroletti SA, Lilly CM. Azacitidineinduced interstitial and alveolar fibrosis in a patient with myelodysplastic syndrome. Pharmacotherapy 25: 765-768, 2005.

8. Hayashi M, Takayasu H, Tada M, et al. Azacitidine-induced pneumonitis in a patient with myelodysplastic syndrome: first case report in Japan. Intern Med 51: 2411-2415, 2012.

9. Sekhri A, Palaniswamy C, Kurmayagari K, Kalra A, Selvaraj DR. Interstitial lung disease associated with azacitidine use: a case report. Am J Ther 19: e98-e100, 2012.

10. Hueser CN, Patel AJ. Azacitidine-associated hyperthermia and interstitial pneumonitis in a patient with myelodysplastic syndrome. Pharmacotherapy 27: 1759-1762, 2007.

11. Naranjo CA, Busto U, Sellers EM, et al. A method for estimating the probability of adverse drug reactions. Clin Pharmacol Ther 30: 239-245, 1981

12. Camus $P$, Costabel U. Drug-induced respiratory disease in patients with hematological diseases. Semin Respir Crit Care Med 26: 458-481, 2005.

13. Limper AH. Chemotherapy-induced lung disease. Clin Chest Med 25: 53-64, 2004.

(C) 2014 The Japanese Society of Internal Medicine http://www.naika.or.jp/imonline/index.html 